\title{
Dialogue between the German Government and Muslims Living in Germany: Prospects and Challenges for the 'Deutsche Islamkonferenz' (DIK)
}

\author{
Christoph Marcinkowski*
}

\section{Beginnings}

In recent decades, Germany has become religiously and culturally more diverse, a fact which is mainly due to the arrival of immigrants from countries with a Muslim background. Meanwhile, approximately four million Muslims live in Germany, and already just under half of them have German citizenship.

In the light of those circumstances, the Deutsche Islamkonferenz (German Islam Conference, DIK), an annual dialogue project launched in 2006, represented the beginning of a long-term dialogue between the German State and Muslims living in Germany. It was initiated by the former Federal Interior Minister Dr Wolfgang Schäuble (CDU). The aim of the initiative was to achieve a better integration of the Muslim population and more togetherness of people living in the Federal Republic, irrespective of faith or ethnic background.

Fifteen representatives of the Federal Government, federal states, and municipalities, as well as 15 Muslims, took part as permanent members. Among the latter were both representatives of various Muslim associations in Germany as well as individuals invited by the Federal Government, including prominent critics. The events were always chaired by the respective interior ministers.

The first three-hour meeting took place on 27 September 2006 in Berlin. This was followed by three further meetings, the last 2009. One of the results so far of the DIK was the establishment of the Coordination Council of Muslims. Dr Schäuble's successors as interior minister, Thomas de Maizière and Hans-Peter Friedrich, continued the DIK project. The first meeting of this second phase took place on 17 May 2010, and the second on 29 March 2011.

According to the Federal Interior Ministry, the aim of the initiative was to establish a viable basis for the relationship between the German State and Muslims living in Germany. According to Schäuble, the issue was not the relationship between Islam and Christianity, but that between the State and religion in general. He reiterated that Muslims need to be made to understand that they are welcome in the country, as this would be the only way to prevent their radicalisation.

* Dr Christoph Marcinkowski is Senior Political Analyst based in Berlin, Germany, since July 2012. From September 2008 to June 2012, he served at IAIS Malaysia as Principal Research Fellow and Associate Editor of this journal. 


\section{Topics Discussed by the DIK}

Among the practical issues discussed so far have been German society and its value consensus (equal rights of husband and wife, secular political system, etc); religious issues from the perspective of the German Federal Constitution (separation of state and church as a basic principle, dealing with religious symbols, mosque constructions, Islamic religious instruction in schools, etc.); business and the media as a bridge (education, vocational training and the labour market, analysis of the current image of Islam in Germany, commitment to unprejudiced and differentiated coverage in the German media); and last but not least security and Islamism (prevention and detection of Islamist violence).

In terms of institutions and organs of the DIK, the Meeting of the Thirty discusses annually the templates of the three working groups and of the discussion circle. Some members of this Meeting (Plenum) work also in advisory bodies of the DIK. A total of about one hundred more professionals and scientists are represented in the advisory committees.

\section{Criticism}

Already in advance of the second meeting of the DIK, criticism grew. CDU/CDU politicians criticised that there were hardly any results and that conservative Muslim representatives would rather work against integration. They were suspicious that Muslim associations would merely take part in the DIK to obtain an officially recognised status for Islam in Germany as a religious community, which would result in more rights. Those associations would show little commitment to the integration policy objectives of the German government. They would represent a rather conservative brand of Islam, with no room for dissent or more liberal views. Participating Muslims, in turn, expressed their lack of understanding the slow progress of rapprochement.

Some have argued that it would be an illusion to believe that the DIK could clarify who should actually speak for the entirety of the Muslims in Germany because the Muslims themselves have not been asked. Only individual Muslim groups which have been asked to participate at the discussion table have a strong interest in establishing a state-recognised speaker role.

In terms of the scope of their supporters, too, the Muslim associations are said to have greatly exaggerated their support. The members of the DIK have been invited, but they wanted to understand themselves as entitled representatives. This seems to be one main problem of the DIK.

Nevertheless, some observers saw successes for the DIK: one of its important achievements, so it was thought, that it has made visible who was actually willing to 
integrate into Germany's society and who not. The importance of the DIK was seen as insisting that this discrepancy between the political desire for participation, along with the declared intention to integrate, and resistance to Germany's secular premises would not be acceptable.

At the 2011 plenary session, the new participating Interior Minister Hans-Peter Friedrich (CSU) repeated his statement made already on the day of his inauguration, that while the presence of Muslims living in Germany is a fact, Islam would not belong to Germany and her culture and historical experience. He called instead for an independent initiative outside the DIK - a "security partnership" between Muslims and the State - in order to raise awareness among Muslim families, fellow believers and members of Muslim clubs and associations for necessary preventive measures against extremist tendencies in the private environment. This statement was criticised by Muslim representatives at the DIK as populism and promotion of an atmosphere of denunciation.

Other critics lamented that the DIK was unilaterally fixated on 'devout' Muslims and organised Islam in the country. This, in particular, would negate the interests of those immigrants from Muslim countries who came to Germany because of religious and political repression in their home countries. Those immigrants would thus be incapacitated (and excluded) from the discourse by a politically enforced (re-) Islamisation. The large-scale construction of mosques, the introduction of Muslim religious instruction in public schools and an Islamically-compliant and politically correct reporting in the media are seen by those critics as part of such an Islamisation by those critics. All this would not promote integration, but would rather support the consolidation of a parallel society.

Again according to those critics, the state should rather demonstrate the principles of a liberal and secular democratic society. Integration would thus presuppose a willingness to accept modern rules of democratic life and to identify with them. The DIK should aim at combating anti-integration attitudes and practices and promote the linguistic and professional integration of migrants. Otherwise the DIK would play into the hands and thus hinder the integration of immigrants. Finally, the participating (selected) Muslim organisations were not empowered to speak on behalf of all immigrants from Muslim countries.

\section{Conclusions and Recommendations}

From the very beginning, the concrete goal of the DIK has been to improve the dialogue between the State and Muslims and thus to contribute to the integration of Muslims into German society and to social cohesion as well as to counter social polarisation and segregation. 
- The DIK was, is not - and cannot be - the representative voice of Muslims in terms of religion, but it is rather a forum for dialogue between representatives of the German State and Muslims living in Germany.

- The DIK should continue to be supervised by the Federal Ministry of the Interior, because this ministry is traditionally responsible for the relations with religious communities in Germany at the level of the Federal Government.

- To strengthen commonalities, to address differences, to promote participation on the basis of Germany's democratic political order: these seem to be the answers to the question of how to achieve social cohesion in a religiously and culturally diverse country like contemporary Germany. Despite severe criticism from several sectors, the DIK project is therefore vital for Germany's social coherence and thus should be continued.

- Muslims living in Germany, in turn, should see themselves as part of German society and should also be understood as such by the non-Muslim German majority.

What is still needed from the part of the Muslim participants is:

- a clear commitment to full compliance with the German legal system, as well as to the values of the Constitution;

- the acceptance of government recommendations for the introduction of Islamic religious education in public schools, for the construction and operation of mosques in Germany, and the legal procedures connected with Muslim burials. Moreover, they need to come to terms with the opportunities and goals for the future training of imams inside Germany;

- a clear commitment to counter extremist aspirations and to establish transparency in Muslim organisations and educational institutions.

In closing, what would also be helpful would be the setting up a clearance office at the Federal Office for Migration and Refugees (BAMF) in order to establish contacts and good examples in the cooperation of Muslims and Germany's security authorities. 